\title{
Phytochemical characterization, antioxidant potential and antimicrobial activity of Averrhoa carambola L. (Oxalidaceae) against multiresistant pathogens
}

\author{
K. B. Silva ${ }^{a}$, C. T. S. Pinheiro ${ }^{b}$, C. R. M. Soares ${ }^{b}$, M. A. Souza ${ }^{b}$ (D), T. J. Matos-Rocha ${ }^{b, c}$ (D),

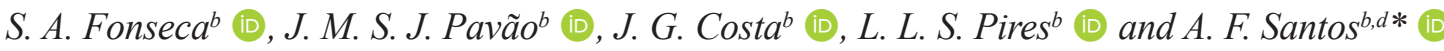 \\ ${ }^{a}$ Universidade Federal de Alagoas - UFAL, Instituto de Química e Biotecnologia, Maceió, AL, Brasil \\ ${ }^{\text {b} C e n t r o ~ U n i v e r s i t a ́ r i o ~ C e s m a c, ~ R u a ~ C o ̂ n e g o ~ M a c h a d o, ~ A l a g o a s, ~ A L, ~ B r a s i l ~}$ \\ 'Universidade Estadual de Ciências da Saúde de Alagoas - UNCISAL, Maceió, AL, Brasil \\ ${ }^{d}$ Universidade Estadual de Alagoas - UNEAL, Arapiraca, AL, Brasil \\ *e-mail: aldenirfeitosa@gmail.com
}

Received: February 20, 2019 - Accepted: February 14, 2020 - Distributed: August 31, 2021

(With 1 figure)

\begin{abstract}
The objective of this work was to perform the phytochemical characterization, to determine total phenols, antioxidant (AAO \%) and antimicrobial potential of the ethanolic extracts of carambola. The phytochemical study was carried out through a qualitative analysis of the chemical constituents and quantitative determination of the phenol content By the Folin-Ciocalteu test. Qualitative and quantitative antioxidant tests were performed using the DPPH method (2,2 diphenyl-1-picryl-hydrazila) and iron reduction (FRAP). The minimum inhibitory concentration (MIC) was determined by microdilution in 96-well plates. The presence of pyrogallic tannins, steroids and saponins has been identified. The highest total phenol content, quantified in the samples, was found in the stem bark $(0.0866 \mathrm{mgEAG} / \mathrm{g})$ and in the fruit $(0.0734 \mathrm{mgEAG} / \mathrm{g})$. In the antioxidant evaluation, the extracts of the green fruit bagasse $(\mathrm{AAO} \% 71.9 \%$, and stem bark at $50 \mu \mathrm{g} / \mathrm{mL}$ (AAO\% 94\%) with CE50 $23.7 \mu \mathrm{g} / \mathrm{mL}$. Leaf extracts, stem bark, ripe fruit bagasse and green fruit bagasse presented MICs of $100 \mu \mathrm{g} / \mathrm{mL}$ against multiresistant pathogenic bacteria and fungi.
\end{abstract}

Keywords: phytochemical screening, total phenols, phenolic compounds, carambola.

\section{Caracterização fitoquímica, potencial antioxidante e atividade antimicrobiana de Averrhoa carambola L. (Oxalidaceae) frente a patógenos multirresistentes}

\begin{abstract}
Resumo
O objetivo desse trabalho foi realizar a caracterização fitoquímica, determinar fenóis totais, potencial antioxidante $(\mathrm{AAO} \%)$ e antimicrobiano dos extratos etanólicos de carambola $\mathrm{O}$ estudo fitoquímico foi realizado por meio de análise qualitativa dos constituintes químicos e determinação quantitativa do teor de fenóis totais pelo teste de Folin-Ciocalteu. Os testes antioxidantes qualitativos e quantitativos foram realizados pelo método do DPPH (2,2 difenil-1- picril-hidrazila) e redução do ferro (FRAP). A concentração inibitória mínima (CIM) foi determinada por microdiluição em placas de 96 poços. Foi identificada a presença de taninos pirogálicos, esteroides e saponinas. O maior teor de fenóis totais, quantificado nas amostras, foi encontrado na casca do caule $(0,0866 \mathrm{mg}$ EAG/g) e no fruto $(0,0734 \mathrm{mg}$ EAG/g). $\mathrm{Na}$ avaliação antioxidante destacaram-se a $500 \mu \mathrm{g} / \mathrm{mL}$ os extratos do bagaço do fruto verde (AAO $\%$ 71,9\%,), e casca do caule a $50 \mu \mathrm{g} / \mathrm{mL}$ (AAO\% 94\%) com $\mathrm{CE}_{50} 23,7 \mu \mathrm{g} / \mathrm{mL}$. Os extratos das folhas, casca do caule, bagaço do fruto maduro e bagaço do fruto verde apresentaram CIM de $100 \mu \mathrm{g} / \mathrm{mL}$ contra bactérias e fungos patogênicos multirresistentes.
\end{abstract}

Palavras-chave: triagem fitoquímica, fenóis totais, compostos fenólicos, carambola.

\section{Introduction}

Averrhoa carambola L. (Oxalidaceae) is an evergreen tree typical of tropical regions being popularly known as carambola (Oliveira et al., 2011). In Brazil the caramboleira is cultivated throughout the country especially in hot regions and in domestic orchards for fruit production, consumed both fresh as well as in sweets and juices (Gol et al., 2015). Chemically the carambola is present in your composition flavonoids, alkaloids, saponins, tannins, vitamins $\mathrm{C}$ and $\mathrm{A}$, calcium and potassium, these compounds which have been commonly studied by being related to antioxidant activity 
and antimicrobial (Khanam et al., 2015). Once the high consumption of natural herbal products for therapeutic purposes has been associated with decreasing incidence of chronic diseases and infectious diseases (Kuhn et al., 2019; Mallmann et al., 2018), this study aimed to perform phytochemical characterization, determining phenols overall, potential antioxidant and antimicrobial activity of etanólicos extracts from different parts of one of the most consumed fruit species in the country, star fruit, as a possible source of antioxidant and natural antimicrobial.

\section{Materials and Methods}

\subsection{Plant sample}

The plant material (bark of the stems, leaves, fruits in State of maturation, unripe fruit and ripe fruit) was identified in the Herbarium of the Environment Institute of Alagoas-IMA, deposited with the registry number 54401.

\subsection{Preparation of the extract}

The sample was weighed and macerated in ethanol at room temperature for 72 hours. The extract was filtered, evaporated in route-Rotary evaporator coupled to vacuum pump for removal of the solvent, so it was retrieved from the ethanolic extract which has been stored and maintained under refrigeration.

\subsection{Qualitative analysis of antioxidant activity}

The extracts were analyzed by thin-layer chromatography (CCD) using default positive comparison routine. The plates were eluted with increasing polarity solvents and, after drying, were sprayed with $0.4 \mathrm{~mol} / \mathrm{L}$ solution of DPPH radical in $\mathrm{MeOH}$. The plates were observed until the appearance of yellow under purple coloring Fund, indicative of possible antioxidant activity.

\subsection{DPPH method (1.1-diphenyl-2-picrilhidrazil)}

The antioxidant potential of the ethanolic extract of propolis was determined by fotocolorimétrico in vitro method held through the kidnapping of free radicals, which was using the DPPH (1.1-diphenyl-2-picril-hidrazila). This analysis is based on ability that the antioxidant compounds have to donate a Proton to the DPPH forming stable resonance structures, stabilizing so called free radical (Brand-Willians et al., 1990; Sánchez, 2002). The extracts were tested at concentrations of $100-500 \mu \mathrm{g} / \mathrm{mL}$ (leaf, fruit pulp, pulp from the fruit pulp of ripe fruit and green) and at concentrations of $0.5-50 \mu \mathrm{g} / \mathrm{mL}$ (bark of the stem). For each concentration, the test was performed in triplicate. In $3 \mathrm{ml}$ of each sample were plus $0.1 \mathrm{~mL}$ of ethanolic solution of DPPH free radical, and incubated for 30 minutes at room temperature, away from light. White used the samples in each of the dilutions. Elapsed time reading the absorbâncias was held in $517 \mathrm{~nm}$ (spectrophotometer) of samples with DPPH against your specific white. How control was used a rate of $0.1 \mathrm{~mL}$ of ethanolic solution of DPPH added $3 \mathrm{ml}$ of ethanol. To evaluate the captadora of free radical activity, the percentage of inhibition was based on equation: $\%$ inhibition $=[$ (control absorbance-absorbance of sample)/ control absorbance] x 100 (Silva et al., 2019; Mensor et al., 2001).

\subsection{Calculation of $E C_{50}$}

The values of total antioxidant activity $(\mathrm{AAO} \%)$ and concentrations $\left(500,250,150,50,10\right.$ and $\left.5 \mu \mathrm{g} / \mathrm{mL}^{-1}\right)$ were related used the "Excel for Windows" program, obtaining, to extract the equation of the line. The resolution of this equation (replacing the Y-value per 50) resulted in the $\mathrm{EC}_{50}$ value, that is the concentration required to produce half $(50 \%)$ of maximum effect estimated at $100 \%$ for A. carambola extracts (Silva et al., 2019).

\subsection{Ferric-reducing Antioxidant Power (FRAP) assay}

The assay was performed according to the method described by Rufino et al. (2006), which is based on the reduction of a ferric tripyridyl triazine complex to its dark blue ferrous form, in the absence and presence of antioxidants. Briefly, the FRAP reagent is prepared by mixing $2.5 \mathrm{~mL}$ of a solution of $10 \mathrm{mmol} \mathrm{L}-1 \mathrm{TPTZ}$ in $40 \mathrm{mmoL} \mathrm{L}-1 \mathrm{HCl}$, and adding $2.5 \mathrm{~mL}$ of $20 \mathrm{mmol} \mathrm{L}^{-1}$ $\mathrm{FeCl} 3$ and $25 \mathrm{~mL}$ of $0.30 \mathrm{~mol} \mathrm{~L}^{-1}$ acetate buffer $(\mathrm{pH}=3.6)$, after which the reagent is heated to $37^{\circ} \mathrm{C}$. Sample aliquots $(90 \mu \mathrm{L})$ were mixed with $270 \mu \mathrm{L}$ of distilled water and $2.7 \mathrm{~mL}$ of FRAP reagent and incubated at $37^{\circ} \mathrm{C}$ for $30 \mathrm{~min}$. The absorbance of the reaction mixture was measured at $595 \mathrm{~nm}$ and a calibration curve was prepared with Trolox ${ }^{\circledR}$ $(5-1000 \mu \mathrm{mol} \mathrm{L}-1)$. The results are expressed as TEACFRAP, i.e., Trolox Equivalent Antioxidant Capacities calculated with respect to the original FRAP in mmol of Trolox $\mathrm{g}^{-1}$.

\subsection{Determination of phenolic compounds}

The ethanolic extract obtained was used for the determination of the levels of total phenolics, by Spectrophotometric method using Folin-Ciocalteau reagent, according methodology described and the calibration curve constructed with Gallic acid standards (10 to $350 \mu \mathrm{g} / \mathrm{mL}$ ) and expressed as mg of EAG (Gallic acid equivalents) per $\mathrm{g}$ of extract (Scherer and Godoy, 2014).

\subsection{Antimicrobial activity test}

The antimicrobial activity was analyzed by the method of microdiluição in broth (Ferreira et al., 2006) with varying statements on final concentrations between 500 to $50 \mu \mathrm{g} / \mathrm{mL}$. We used standard strains of Staphylococcus aureus ATCC 29213 (MRSA), Staphylococcus saprophyticus ATCC 25352, Enterococcus faecalis ATCC 29212, Enterobacter aerogenes ATCC 13048, Klebsiella pneumoniae ATCC BAA-1705 (KPC), Proteus mirabilis ATCC 25933, Escherichia coli ATCC 25922, Pseudomonas aeruginosa ATCC 27853, Acinetobacter baumannii ATCC 17978, and clinical isolates of $S$. aureus, E. aerogenes, K. pneumoniae, E. coli, P. aeruginosa and A. baumannii with multidrug resistance profile obtained from samples clinics. The fungi examined were Candida albicans ATCC 200955 and C. krusei ATCC 200917. The Minimum inhibitory concentration was defined as the lowest concentration able to inhibit microbial growth. Statistical analyses were performed using the Assistat program (7.6). The variance analysis 
of the experiment was determined using the Dunnett test at the level of $5 \%$ probability.

\subsection{Phytochemical analysis of the extract}

To perform the phytochemical screening stage was based on the methodology proposed by Matos and Matos (1989) which has been crafted with some adaptations in order to carry out prospecting the following allelochemicals: phenols, pyrogalic tannins, phlobaphene tannins, anthocyanin and anthocyanidin, flavones, flavonols, xanthones, chalcones, aurones, flavononois, leucoantocianidinas, catechins, flavonones, flavonols, xanthones, steroids and triterpenoids saponins. Of each extract obtained and used in bioassays from $35 \mathrm{~mL}$ to the phytochemical prospecting, which have been split into seven portions of $3 \mathrm{~mL}$ test tubes numbered and identified according to each type of extract and one $10 \mathrm{~mL}$ portion in beakers labeled. Heated the beaker in a Bain-Marie by means of a hot plate with agitation until the total evaporation from the liquid, which was used in tests for steroids, and triterpenoid saponins.

\section{Results and Discussion}

The present study has shown that saponins, tannins and pyrogalic steroids presented himself as the most frequent among the compounds studied, in various parts of vegetables star fruit (Table 1). The great interest around these classes of secondary metabolites is the correlation that these compounds have with various biological activities, such as antioxidant and antimicrobial activities among other (Kuhn et al., 2019; Mallmann et al., 2018; Milani et al., 2012). A diet abundant in some of these compounds is able to act in the prevention of various diseases. Compounds such as saponins are related to action detergent and emulsifier, expectorant and diuretic (Kaneshima et al., 2016), anti-inflammatory (Xiong et al., 2015), antifungical (Woldemichael and Wink, 2001). The tannins have astringent, antidiarrheal drug effects, antimicrobial, antiseptic and the flavonoids, abundant in fruits, have anti-inflammatory properties, antibacterial, antifungal, antioxidant and anticâncer (Kaneshima et al., 2016). The presence of these compounds in the extracts corroborates with the antioxidant and antimicrobial potential presented by various parties studied the A. carambola.

Regarding the antioxidant potential, all the extracts were active, the stem bark was highlighted by presenting $\mathrm{AAO} \% 94.05$ to $50 \mu \mathrm{g} / \mathrm{mL}$ and $\mathrm{EC}_{50} 28.5 \pm 2.9 \mu \mathrm{g} / \mathrm{mL}$, the other extracts presented AAO $\%>59 \%$ at $500 \mu \mathrm{g} / \mathrm{mL}$. All values of $\mathrm{R}^{2}$ (coefficient of determination) were higher than 0.9 (Figure 1). Through Dunnett's test, it was possible to verify the existence of a significant difference $(\mathrm{P}<0.05)$ between the antioxidant potential of the stem bark and the other plant extracts evaluated.

The antioxidant potential of carambola against the DPPH radical was higher than that presented by Cinnamomum camphora $\left(500 \mu \mathrm{g} / \mathrm{mLAAO} \% 7.11 \%\right.$ EC $\left._{50} 12942 \mu \mathrm{g} / \mathrm{mL}\right)$ and Terminalia brasiliensis (AAO\% 6.0\%) (Cansian et al., 2010; Sousa et al., 2007), and the results obtained in pineapple, cashew, passion fruit and mango residues $(5.63 \pm 0.25$; $68.60 \pm 0.23 ; 10.29 \pm 0.44$ and $33.03 \pm 2.40 \mu \mathrm{mol}$ et/g of dry matter, respectively) (Infante et al., 2013). The production and concentration of phytoantioxidants can vary and also depends on environmental conditions. They can be induced or regulated by stress conditions such as high radiation, temperature, mineral imbalance or even pathogenic attacks subjected to each part of the studied fruit (Neill et al., 2002; Wilmes et al., 2011). In the antioxidant assays DPPH Trolox and FRAP Trolox The plant samples also presented antioxidant activity, with determination of the calibration curve of the synthetic Trolox pattern $(y=-0.006 x+0.6882$, $\left.\mathrm{R}^{2}=0.99 ; 0.000704 \mathrm{x}+0.0144, \mathrm{r}^{2}=0.99\right)$ respectively (Table 2), highlighting the stem bark of this fruit.

By determining the calibration curve of the synthetic gallic acid pattern $\left(y=7.701 x+0.0131\right.$ and $\left.\mathrm{R}^{2}=0.99\right)$ It was possible to quantify the total phenols in all the extracts (Table 2). The stem bark presented the highest

Table 1. Classes of secondary metabolites detected in extracts of Averrhoa carambola.

\begin{tabular}{lccccc}
\hline \multirow{2}{*}{ Class of compounds } & \multicolumn{4}{c}{ Ethanolic Extract } & \\
\cline { 2 - 5 } & $\begin{array}{c}\text { Green Fruit } \\
\text { Bagasse }\end{array}$ & $\begin{array}{c}\text { Ripe fruit } \\
\text { bagasse }\end{array}$ & Leaf & Stem bark & Fruit pulp \\
\hline Phenols & $\mathrm{A}$ & $\mathrm{A}$ & $\mathrm{A}$ & $\mathrm{A}$ & $\mathrm{A}$ \\
Pyrogallic tannins & $\mathrm{P}$ & $\mathrm{P}$ & $\mathrm{P}$ & $\mathrm{P}$ & $\mathrm{A}$ \\
Phlobaphene tannins & $\mathrm{A}$ & $\mathrm{A}$ & $\mathrm{A}$ & $\mathrm{A}$ & $\mathrm{A}$ \\
Anthocyanin and anthocyanidin & $\mathrm{A}$ & $\mathrm{A}$ & $\mathrm{A}$ & $\mathrm{A}$ & $\mathrm{A}$ \\
Chalcones and aurones & $\mathrm{A}$ & $\mathrm{A}$ & $\mathrm{A}$ & $\mathrm{A}$ & $\mathrm{A}$ \\
Flavononols & $\mathrm{A}$ & $\mathrm{A}$ & $\mathrm{A}$ & $\mathrm{P}$ & $\mathrm{P}$ \\
Leucoanthocyanidins & $\mathrm{A}$ & $\mathrm{A}$ & $\mathrm{A}$ & $\mathrm{A}$ & $\mathrm{A}$ \\
Catechins & $\mathrm{P}$ & $\mathrm{A}$ & $\mathrm{A}$ & $\mathrm{P}$ & $\mathrm{P}$ \\
Flavonones & $\mathrm{A}$ & $\mathrm{A}$ & $\mathrm{A}$ & $\mathrm{P}$ & $\mathrm{P}$ \\
Flavones, flavonols and xanthones & $\mathrm{P}$ & $\mathrm{A}$ & $\mathrm{A}$ & $\mathrm{A}$ & $\mathrm{A}$ \\
Steroids & $\mathrm{P}$ & $\mathrm{P}$ & $\mathrm{P}$ & $\mathrm{P}$ & $\mathrm{A}$ \\
Triterpenoids & $\mathrm{A}$ & $\mathrm{A}$ & $\mathrm{A}$ & $\mathrm{A}$ & $\mathrm{A}$ \\
Saponins & $\mathrm{P}$ & $\mathrm{P}$ & $\mathrm{P}$ & $\mathrm{P}$ \\
\hline
\end{tabular}

Absent (A), Presence (P). 

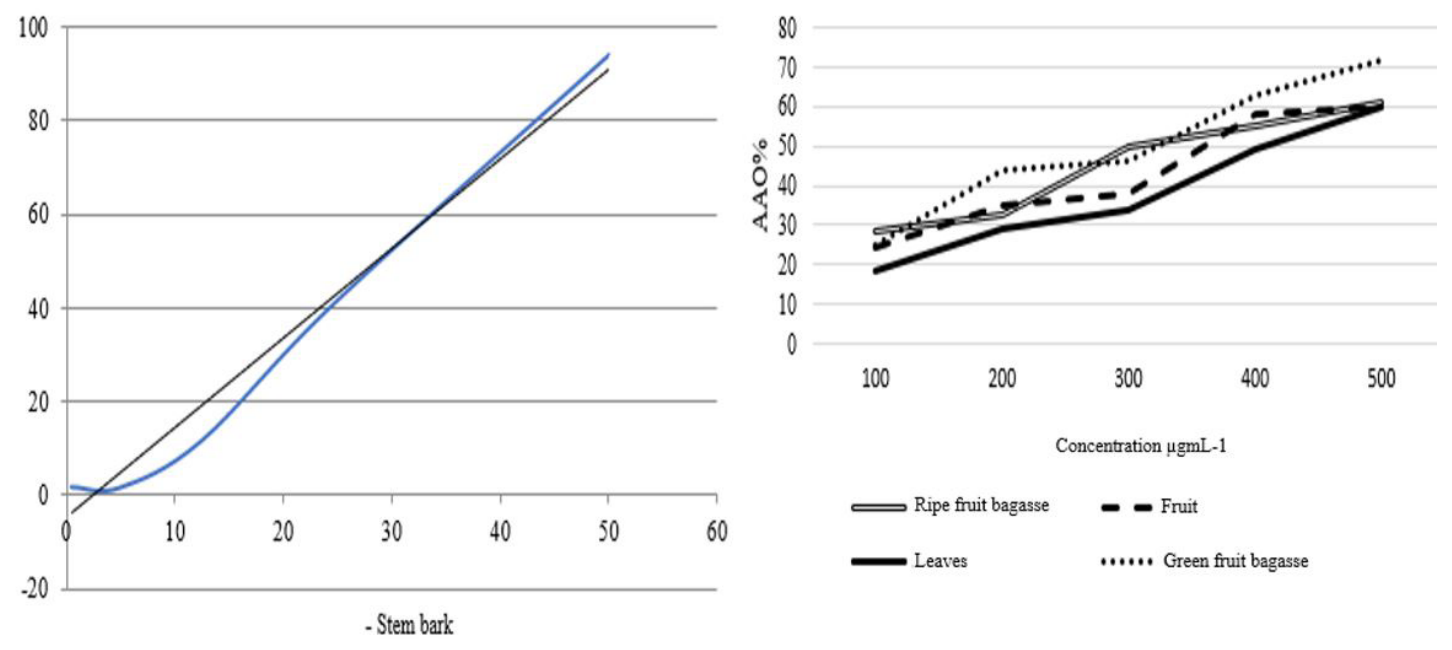

\begin{tabular}{|l|c|c|c|}
\cline { 2 - 4 } \multicolumn{1}{c|}{} & Equation of the line & $\mathbf{R}^{\mathbf{2}}$ & $\begin{array}{c}\text { CE50 } \\
(\boldsymbol{\mu g} / \mathbf{m L} \pm \text { standard deviation) }\end{array}$ \\
\hline Stem Bark & $\mathrm{y}=1.9146 \mathrm{x}-4.6171$ & 0.9810 & $28.52 \pm 2.9$ \\
\hline Ripe fruit bagasse & $\mathrm{y}=0.0872 \mathrm{x}+19.302$ & 0.9461 & $352.04 \pm 52.0$ \\
\hline Green Fruit bagasse & $\mathrm{y}=0.1134 \mathrm{x}+15.964$ & 0.9619 & $300.14 \pm 25.2$ \\
\hline Leaf & $\mathrm{y}=0.1031 \mathrm{x}+7.3267$ & 0.9792 & $413.9 \pm 4.0$ \\
\hline Pulp & $\mathrm{y}=0.0936+14.863$ & 0.9313 & $375.3 \pm 83.2$ \\
\hline
\end{tabular}

Figure 1. Evaluation of antioxidant activity through the kidnapper of DPPH radical activity of Averrhoa carambola.

Table 2. Spectrophotometric analyses of total phenols and antioxidants DPPH and FRAP.

\begin{tabular}{|c|c|c|c|}
\hline \multirow{2}{*}{ Ethanolic Extract } & *DPPH Trolox & **FRAP Trolox & $* * *$ TFT \\
\hline & $\mu \mathrm{mol}$ ET/g amostra & $\mu \mathrm{mol}$ ET/g amostra & mg EAG/g amostra \\
\hline Fruit pulp & $429.55 \pm 151.08$ & $7106.72 \pm 649.12$ & $143.91 \pm 13.16$ \\
\hline Green Fruit Bagasse & $198.44 \pm 65.43$ & $4738.12 \pm 1019.33$ & $97.90 \pm 16.51$ \\
\hline Ripe fruit bagasse & $225.11 \pm 18.35$ & $5284.43 \pm 1141.30$ & $214.92 \pm 9.80$ \\
\hline Stem Bark & $1971.77 \pm 10.71$ & $79932.29 \pm 269.06$ & $3891.87 \pm 81.39$ \\
\hline Leaf & $1040.66 \pm 23.09$ & $11162.20 \pm 2395.23$ & $470.76 \pm 3.01$ \\
\hline
\end{tabular}

*Antioxidant activity DPPH with synthetic Trolox pattern (Mmol trolox equivalent/g sample). **Reduction of FRAP iron (Mmol trolox equivalent/g sample). ${ }^{* *}$ Total phenolic content TFT (mg equivalent of galic acid/g of dry extract). Mean \pm standard deviation $(n=3)$. ET - Ethanol extract; EAG - Gallic acid equivalents.

index of phenols with $3891.87 \mathrm{mg}$ of eag/g of crude extract, which is consistent with its expressive antioxidant potential. These results were higher han those presented by blueberry $(7,26)$, strawberry $(7,72)$ and blackberry $(13,22)$ (Silva et al., 2011), Jenipap $(15.43 \pm 0.70)$ and umbu (19.71 \pm 1.47$)$, (Omena et al., 2012), pineapple $(5,63 \pm 0,25)$ and cashew $(10,29 \pm 0,44)$ (Infante et al., 2013).

The extracts of stem bark, leaves and fruits of $A$. carambola showed antibacterial and antifungal activity. The lowest inhibitory concentration presented by the extracts was $100 \mu \mathrm{g} / \mathrm{mL}$ (Table 3), considered strong antibacterial and antifungal activity, because according to Sartoratto et al. (2004), a strong activity of plant extracts would be for mic values between $50-500 \mu \mathrm{g} / \mathrm{mL}$. The crude leaf extract presented a broad spectrum of action against Gram-positive and Gram-negative bacteria, such as S. aureus ATCC 29213 MRSA, S. aureus $6 \mathrm{MRSA}$, S. aureus $10 \mathrm{MRSA}, S$. aureus 12 MRSA, E. faecalis ATCC 29212, K. pneumoniae $8 \mathrm{ESBL}$ and $A$. baumannii $2 \mathrm{MBL}$, even in the face of multidrug-resistance mechanisms. However, it did not present antifungal activity in relation to the other extracts. The extracts of the bagasse of the ripe fruit and the bark presented antistaphylococcal action, as well as the extracts of the leaf. The extract of the green fruit bagasse when compared to that of the ripe bagasse, was restricted only to the antifungal activity.

The extracts showed activity, even in the face of multidrug-resistant strains, demonstrating that the resistance of wild strains did not interfere with the activity of plant extracts of the carambola. This result is promising due to 
Table 3. Antimicrobial activities of extracts from Averrhoa carambola as determined using the Minimum inhibitory concentration.

\begin{tabular}{|c|c|c|c|c|}
\hline \multirow[b]{2}{*}{ Microorganisms } & \multicolumn{4}{|c|}{ Crude extracts $(\mu \mathrm{g} / \mathrm{mL})$} \\
\hline & Leaf & Bark & $\begin{array}{l}\text { Ripe fruit } \\
\text { bagasse }\end{array}$ & $\begin{array}{c}\text { Green Fruit } \\
\text { Bagasse }\end{array}$ \\
\hline \multicolumn{5}{|l|}{ Bacteria species } \\
\hline Staphylococcus aureus ATCC 29213 MRSA & 100 & 100 & 100 & - \\
\hline Staphylococcus aureus 6 MRSA & 100 & 100 & 100 & - \\
\hline Staphylococcus aureus $10 \mathrm{MRSA}$ & 100 & 100 & 100 & - \\
\hline Staphylococcus aureus $12 \mathrm{MRSA}$ & 100 & 100 & 100 & - \\
\hline Staphylococcus saprophyticus ATCC 25352 & - & - & - & - \\
\hline Enterococcus faecalis ATCC 29212 & 100 & - & 100 & - \\
\hline Escherichia coli ATCC 25922 & - & - & - & - \\
\hline Escherichia coli $67 \mathrm{ESBL}$ & - & - & - & - \\
\hline Klebsiella pneumoniae 8 ESBL & 100 & 100 & - & - \\
\hline Proteus mirabilis ATCC 25933 & - & - & - & - \\
\hline Enterobacter aerogenes $12 \mathrm{KPC}$ & - & - & - & - \\
\hline Pseudomonas aeruginosa ATCC 27853 & - & - & - & - \\
\hline Pseudomonas aeruginosa $31 \mathrm{MBL}$ & - & - & - & - \\
\hline Acinetobacter baumannii $2 \mathrm{MBL}$ & 100 & - & - & - \\
\hline \multicolumn{5}{|l|}{ Fungal species } \\
\hline Candida albicans ATCC 200955 & - & 100 & 100 & 100 \\
\hline Candida krusei ATCC 200917 & - & 100 & 100 & 100 \\
\hline
\end{tabular}

MRSA - Methicillin-resistant Staphylococcus aureus; ESBL - Extended-spectrum beta-lactamases; MBL - metallo-beta-lactamases; ATCC - American Type Culture Collection; KPC - Klebsiella Pneumoniae Carbapenemase.

the increasing pace of resistance occurring in different pathogens, representing a major therapeutic challenge (Rossi, 2011). The extracts with antistaphylococcal action may represent an alternative for the discovery of new antibiotics, since vancomycin is one of the few therapeutic options for methicillin-resistant Staphylococcus aureus (MRSA) (Gardete and Tomasz, 2014).

Enterococcus may be the cause of at least $10 \%$ of hospital infections, with high levels of resistance (Prieto et al., 2016), so antimicrobial action studies of plant extracts have been carried out (Costa et al., 2010). The extracts of the leaf and the bagasse of the ripe fruit of the carambola were effective against a wild strain of E. Faecalis, which represents about 85 to $90 \%$ of the Enterococcos isolated in the clinic (Prieto et al., 2016).

Gram-negative bacteria have been a frequent problem in the hospital environment because they have the ability to develop mechanisms of mainly enzymatic resistance. The treatment of infections caused by strains of $K$. pneumoniae is difficult due to the existence of strains carrying plasmids, which encode enzymes known as beta-lactamases (ESBL), thus conferring resistance to beta-lactam. The extracts of the leaves and the $A$. carambola bark showed activity front $K$. pneumoniae which is the main species producing ESBL responsible for 2 to $5 \%$ of the nosocomial infections, mainly respiratory and urinary as reported by Scarpate and Cossatis (2009).

The antimicrobial activity assays also inhibited the growth of $A$. baumannii multiresistant producer of metallo-beta-lactamases, a carbapenemic inhibitory enzyme, through the leaf extract of $A$. carambola. A. baumanni has become an important pathogen in recent years due to the increasing number of hospital outbreaks (Cirino et al., 2008). The activity against fungi of medical interest was observed in the extracts of the peel and fruits, including the extract of the bagasse of the green fruit that did not present antibacterial action (Table 3 ). Therefore, the importance of the antifungal activity detected, because the resistance based on different mechanisms continues to grow and exacerbate the need for new treatments against Candida infections.

\section{Conclusion}

Under the conditions of this study, our results showed that A. carambola has antioxidant and antimicrobial activities. The activities presented may be related to the presence of phenolic substances in extracts. It is of great importance the isolation of the chemical constituents of this species, so that they can be tested in experimental models, and thus determine the compounds responsible for the biological activities of extracts.

\section{References}

BRAND-WILLIANS, W., CUVELIER, M.E. and BERSET, C., 1990. Use of free radical method evaluate oxidante activity. Lebensm-wiss. Techonology, vol. 28, pp. 25-30.

CANSIAN, R.L., MOSSI, A.J., OLIVEIRA, D., TONIAZZO, G., TREICHEL, H., PAROUL, N., ASTOLFI, V. and SERAFINI, L.A., 2010. Atividade antimicrobiana e antioxidante do óleo essencial de ho-sho (Cinnamomum camphora Ness e Eberm Var. 
Linaloolifera fujita). Food Science and Technology (Campinas), vol. 30, no. 2, pp. 378-384. http://dx.doi.org/10.1590/S010120612010000200014 .

CIRINO, P.V., GUIMARÃES, N.S. and FOLLADOR, I., 2008. Infecção cutânea rara por Acinetobacter baumannii em imunocompetente: relato de um caso. Anais Brasileiro de Dermatologia, vol. 83, no. 4, pp. 335-338.

COSTA, E.M.M.B., BARBOSA, A.S., ARRUDA, T.A., OLIVEIRA, P.T., DAMETTO, F.R., CARVALHO, R.A. and MELO, M.D., 2010. Estudo in vitro da ação antimicrobiana de extratos de plantas contra Enterococcus faecalis. Jornal Brasileiro de Patologia e Medicina Laboratorial, vol. 46, no. 3, pp. 175-180. http://dx.doi. org/10.1590/S1676-24442010000300004.

FERREIRA, L.M.R., DE LIMA, M.R., DE SOUZA LUNA, J., DOS SANTOS, A.F., DE ANDRADE, M.C., SANT'ANA, A.E., GENET, J.P., MARQUEZ, B., NEUVILLE, L. and MOREAU, N., 2006. Anti-bacterial activity of some Brazilian medicinal plants. Journal of Ethnopharmacology, vol. 105, no. 1-2, pp. 137-147. http://dx.doi.org/10.1016/j.jep.2005.10.026. PMid:16356672.

GARDETE, S. and TOMASZ, A., 2014. Mechanisms of vancomycin resistance in Staphylococcus aureus. The Journal of Clinical Investigation, vol. 124, no. 7, pp. 2836-2840. http:// dx.doi.org/10.1172/JCI68834. PMid:24983424.

GOL, N.B., CHAUDHARI, M.L. and RAO, T.V.R., 2015. Effect of edible coatings on quality and shelf life of carambola (Averrhoa carambola L.) fruit during storage. Journal of Food Science and Technology, vol. 52, no. 1, pp. 7-91. http://dx.doi.org/10.1007/ s13197-013-0988-9.

INFANTE, J., SELANI, M.M., TOLEDO, N.M.V., SILVEIRADINIZ, M.F., ALENCAR, S.M. and SPOTO, M.H.F., 2013. Atividade antioxidante de resíduos agroindustriais de frutas tropicais. Alimentos e Nutrição, vol. 24, no. 1, pp. 87-91.

KANESHIMA, A.M.S., KANESHIMA, E.N., CAVALCANT, A.V. and WIDERSKI, K., 2016. Estudo terapêutico e geoecológico do Stryphnodendron adstringens (mart.) Coville: uma revisão integrativa. Revista Conhecimento e Sociedade, vol. 1, no. 1, pp. $\mathrm{x}-\mathrm{xx}$.

KHANAM, Z., SAM, K.H., ZAKARIA, N.H.B.M., CHING, C.H. and BHAT, I.U.H., 2015. Determination of polyphenolic content, HPLC analyses and DNA cleavage activity of Malaysian Averrhoa carambola L. fruit extracts. Journal of King Saud University Science, vol. 27, no. 4, pp. 33-337. http://dx.doi.org/10.1016/j. jksus.2015.01.004.

KUHN, D., ZIEM, R., SCHEIBEL, T., BUHL, B., VETTORELLO, G., PACHECO, L.A., HEIDRICH, D., KAUFFMANN, C., FREITAS, E.M., ETHUR, E.M. and HOEHNE, L., 2019. Antibiofilm activity of the essential oil of Campomanesia aurea O. Berg against microorganisms causing food borne diseases. Food Science and Technology, vol. 108, pp. 247-252. https:// doi.org/10.1016/j.lwt.2019.03.079.

MALLMANN, R., ETHUR, E.M., BIANCHETTI, P., FALEIRO, D., HOEHNE, L. and GOETTERT, M.I., 2018. Effectiveness of aqueous and hydroalcoholic extracts of Acanthospermum australe (Loefl.) Kuntze against diarrhea-inducing bactéria. Brazilian Journal of Biology $=$ Revista Brasleira de Biologia, vol. 78, no. 4, pp. 619-624. http://dx.doi.org/10.1590/1519-6984.167376. PMid:29319752.

MATOS J. M. D. and MATOS, M. E. O., 1989. Farmacognosia: curso teórico - prático. Fortaleza: Edições UFC.
MENSOR, L.L., MENEZES, F.S., LEITÃO, G.G., REIS, A.S., SANTOS, T.C., COUBE, C.S. and LEITÃO, S.G., 2001. Screening of Brazilian plant extracts for antioxidant activity by the use of DPPH free radical method. Phytotherapy Research, vol. 15, no. 2, pp. 127-30. http://dx.doi.org/10.1002/ptr.687. PMid:11268111.

MILANI, L.I.G., TERRA, N.N., FRIES, L.L.M., CICHOSKI, A.J., REZER, A.P.S., BACKES, A.M. and PARODIA, C.G., 2012. Atividade antioxidante e antimicrobiana in vitro de extratos de caqui (Diospyros kaki L.). Brazilian Journal Food and Techinology, vol. 15 , no. 2 , pp. 118-124.

NEILL, S.O., GOULD, K.S., KILMARTIN, P.A., MITCHELL, K.A. and MARKHAM, K.R., 2002. Antioxidant activities of red versus green leaves in Elatostema rugosum. Pant and Cellular and Environment, vol. 25, no. 4, pp. 539-547. http://dx.doi. org/10.1046/j.1365-3040.2002.00837.x.

OLIVEIRA, D.S., AQUINO, P.P., RIBEIRO, S.M. R., PROENÇA, R.P.C. and PINHEIRO-SANT'ANA, H.M., 2011. Vitamina C, carotenoides, fenólicos totais e atividade antioxidante de goiaba, manga e mamão procedentes da Ceasa do Estado de Minas Gerais. Acta Scientiarum. Health Sciences, vol. 33, no. 1, pp. 89-98.

OMENA, C.M.B., VALENTIM, I.B., GUEDES, G.S., RABELO, L.A., MANO, C.M., BECHARA, E.J.H. and GOULART, M.O.F., 2012. Antioxidant, anti-acetylcholinesterase and cytotoxic activities of ethanol extracts of peel, pulp and seeds of exotic Brazilian fruits. Food Research International, vol. 49, pp. 334-344.

PRIETO, A.M.G., VAN SCHAIK, W., ROGERS, M.R.C., COQUE, T.M., BAQUERO, F., CORANDER, J. and WILLEMS, R.J.L., 2016. Global Emergence and Dissemination of Enterococci as Nosocomial Pathogens: attack of the Clones? Frontiers in Microbiology, vol. 7, no. 788, pp. 1-15. PMid:27303380.

ROSSI, F., 2011. The challenges of antimicrobial resistance in Brazil. Clinical Infectious Diseases, vol. 52, no. 9, pp. 1138-1143. http://dx.doi.org/10.1093/cid/cir120. PMid:21467020.

RUFINO, M. S. M., ALVES, R. E., BRITO, E. S., MORAIS, S. M., SAMPAIO, C. G., PÉREZ-JIMÉNEZ, J. and SAURA-CALIXTO, F. D., 2006. Determinação da atividade antioxidante total em frutas pelo método de redução do ferro (FRAP). Fortaleza: Embrapa Agroindústria Tropical, 4 p. Comunicado Técnico on-line, no. 125.

SÁNCHEZ, M.C., 2002. Review: methods used to evaluate the free radical scavenging activity. Foods and Biological Systems, vol. 1 , no. 1 , pp. 121-137.

SARTORATTO, A., MACHADO, A.L.M., DELARMELINA, C., FIGUEIRA, G.M., DUARTE, M.C.T. and REHDER, V.L.G., 2004. Composition and antimicrobial activity of essential oils from aromatic plants used in Brazil. Brazilian Journal of Microbiology, vol. 35 , no. 4 , pp. $275-280$. http://dx.doi.org/10.1590/S151783822004000300001

SCARPATE, E.C. and COSSATIS, J.J., 2009. A presença da Klebsiella pneumoniae produtora de $\beta$-lactamase de espectro estendido no ambiente hospitalar. Saúde e Ambiente, vol. 4, no. 1 , pp. 1-11.

SCHERER, R. and GODOY, H.T., 2014. Effects of extraction methods of phenolic compounds from Xanthium strumarium L. and their antioxidant activity. Revista Brasileira de Plantas Medicinais, vol. 16, no. 1, pp. 41-46. http://dx.doi.org/10.1590/ S1516-05722014000100006.

SILVA, F.R.G., MATIAS, T.M.S., SOUZA, L.I.O., MATOSROCHA, T.J., FONSECA, S.A., MOUSINHO, K.C. and SANTOS, A.F., 2019. Phytochemical screening and in vitro 
antibacterial, antifungal, antioxidant and antitumor activities of the red propolis Alagoas. Brazilian Journal of Biology $=$ Revista Brasileira de Biologia, vol. 79, no. 3, pp. 452-459. http://dx.doi. org/10.1590/1519-6984.182959. PMid:30379200.

SILVA, R.S., VENDRUSCOLO, J.L. and TORALLES, R.P., 2011. Avaliação da capacidade antioxidante em frutas produzidas na região sul do RS. Revista Brasileira de Agrociência, vol. 17, no. 3-4, pp. 392-400.

SOUSA, C.M.M., SILVA, H.R.E., VIEIRA-JR., G. M., AYRES, M. C. C., COSTA, C. L. S., ARAÚJO, D. S., CHAVES, M. H., 2007. Fenóis totais e atividade antioxidante de cinco plantas medicinais. Química Nova, vol. 30, no. 2, pp. 351-355. http:// dx.doi.org/10.1590/S0100-40422007000200021.
WILMES, A., CREAN, D., AYDIN, S., PFALLER, W., JENNINGS, P. and LEONARD, M.O., 2011. Identification and dissection of the Nrf2 mediated oxidative stress pathway in human renal proximal tubule toxicity. Toxicology In Vitro, vol. 25, no. 3, pp. 613-622. http://dx.doi.org/10.1016/j.tiv.2010.12.009. PMid:21172416.

WOLDEMICHAEL, G.M. and WINK, M., 2001. Identification and biological activities of triterpenoid saponins from Chenopodium quinoa. Journal Agricultural and Food Chemistry, vol. 49, no. 5, pp. 2327-2332.

XIONG, H., ZHENG, Y., YANG, G., WANG, H. and MEI, Z., 2015. Triterpene saponins with anti-inflammatory activity from the stems of Entada phaseoloides. Fitoterapia, vol. 103, pp. 33-45. http://dx.doi.org/10.1016/j.fitote.2015.03.001. PMid:25759122. 